\title{
Intersections
}

Canadian Journal of Music

Revue canadienne de musique

\section{How I Might Have Become a Composer}

\section{Brian Cherney}

Volume 37, numéro 1, 2017

Illuminations: Essays in Honour of Brian Cherney

URI : https://id.erudit.org/iderudit/1059883ar

DOI : https://doi.org/10.7202/1059883ar

Aller au sommaire du numéro

\section{Éditeur(s)}

Canadian University Music Society / Société de musique des universités canadiennes

\section{ISSN}

1911-0146 (imprimé)

1918-512X (numérique)

Découvrir la revue

Citer cet article

Cherney, B. (2017). How I Might Have Become a Composer. Intersections, 37(1), 9-17. https://doi.org/10.7202/1059883ar

\section{Résumé de l'article}

Brian Cherney réfléchit sur son enfance et sa jeunesse à Peterborough (Ontario) dans les années 1940 et 1950, ainsi que ses études musicales à l’Université de Toronto. Il examine l'influence qu'ont eue, à divers degrés, sa famille, l'écoute d'enregistrements et de radiodiffusions de la $\mathrm{CBC}$, la fréquentation des concerts, les leçons de piano, la lecture d'écrits sur la musique et les séjours en Europe à la fin des années 1960 sur son intérêt croissant pour la composition. Selon lui, ce n'est que vers le milieu des années 1970, après sa nomination à McGill en 1972, qu'il a acquis la conscience de soi, l'esprit critique et la confiance nécessaires pour devenir un compositeur sérieux, quelqu'un qui, pour reprendre les paroles de T.S. Eliot, ose « déranger l'univers ".
Copyright (C Canadian University Music Society / Société de musique des universités canadiennes, 2019
Ce document est protégé par la loi sur le droit d'auteur. L’utilisation des services d’Érudit (y compris la reproduction) est assujettie à sa politique d'utilisation que vous pouvez consulter en ligne.

https://apropos.erudit.org/fr/usagers/politique-dutilisation/ 


\title{
HOW I MIGHT HAVE BECOME A COMPOSER
}

\author{
Brian Cherney
}

The title of this article is, admittedly, somewhat mischievous.

Does it mean that there were things I might have done to become a composer if only I had tried harder? This implies, obviously, that I never managed to become a composer. Some of my relatives and certain genteel critics of the conservative persuasion would probably agree.

Or ... does it mean that I am about to suggest a possible explanation for how it happened that I did become a composer (if, indeed, I did)? And to broaden the horizon a bit, how does it happen that anybody becomes a composer?

In this case, it's the last question I am asking. And more particularly, how did it happen that a boy growing up in the small Ontario town of my childhood and youth in the late 1940 os and 1950 os began to write music? Not pop songs or rock and roll or other such music, which was then dominant, but "classical" music, considered (if thought about at all) very weird and unusual in most social circles in a small town.

If there were any obvious role models for someone's career in those days, being a composer (let alone a "classical" composer) was not exactly at the top of the list. I don't know if even hockey players had yet become such role models. As a young lad I used to listen to a radio program called Sergeant Preston of the Yukon; for a time I couldn't imagine anything more noble or exciting than becoming a Mountie. But genetic factors and other circumstances ensured that this would never come to be. For one thing, I was Jewish. There were probably fewer Jews in the RCMP in those days than in Toronto's Granite Club or on the medical staff of Toronto General Hospital.

I am convinced that genetic factors played a great part in my interest in music. My mother, who grew up in Toronto, came from an immigrant family with a lot of musically gifted people over several generations. Her uncle, Nathan Green, played viola with the Toronto Symphony for some forty years. His son, my mother's cousin, was also a professional violist. An aunt of hers had studied piano, and another cousin had studied violin at Juilliard. My grandfather had never studied music but could play the piano by ear. His mother, my great-grandmother, apparently loved opera and, according to my great-uncle Nate, an ancestor in the nineteenth century had been a well-known violinist in Europe (wherever they came from-I don't know where). My mother had studied piano in her youth-throughout my childhood she continued to take 
piano lessons with a wonderful pianist named Agnes Logan Green, and she played the piano every evening-Bach, Schumann, Brahms, Debussy, and various other composers' music drifted upstairs to my bedroom while I was falling asleep. Needless to say, at an early age I was subjected to piano lessons (I think I was about five when I began lessons). Apparently in one of my early Royal Conservatory exams the examiner, Earle Moss, wrote on the report that I was "a real little musician." My mother must have been delighted to see this, and it probably made her all the more determined to have me apply myself diligently to the piano. (For her, the highest calling in life-the most powerful "role model"-was that of an "artist" - a great musician or writer, or some such figure. I was much more interested in the "Mountie" project.)

So this may explain where the musical interest came from. After all, my brother also became a musician. And this might have led to my becoming yet another pianist or piano teacher. Who knows? Now, if my father had married some other woman with no musical ability or musical heritage in her family, it's safe to say that I would not even have become a musician, let alone a composer. The fact that my father (who did not have obvious musical interest or talent in his family, except for an elder sister who sang) married my mother was entirely Lou Applebaum's doing. And thus Lou unwittingly became the agent of my fate. For those who do not know who Lou Applebaum was, he was one of the most important figures in the arts in Canada in the second half of the twentieth century. Not only was he a fine composer who wrote scores for the National Film Board and even for a few Hollywood films, but he was the founder of the music section of the Stratford Festival in the 1950s, was active at CAPAC and the Ontario Arts Council, and was the co-author of the Applebaum-Hébert Report on the arts in the early 1980s. Lou had known my mother at the University of Toronto in the mid-193os and had, at the same time, met my father in the small Ontario town where he lived, because Lou spent his summers going around small-town Ontario selling magazine subscriptions to put himself through university. Apparently in the late summer of 1937 he introduced my parents to each other at the CNE, where my mother had a summer job working for a cosmetics company. Two years later they were married and my mother moved to small-town Ontario to become a wife and mother.

Besides listening to my mother play the piano, there were various other ways of hearing music during my childhood, and music was certainly my central interest and passion, outside of riding my bicycle and running my electric train. Around 1949/50 long-playing records (LPs) appeared on the scene, and my father not only sold them at his retail furniture store but brought them home and early on acquired a good turntable, amplifier, and speaker; they were located in the book-lined den of our house, and I listened to all kinds of music there, ranging from Bach's Brandenburg Concertos (my favourite) to Bartók's Concerto for Orchestra and Mozart Piano Concertos. I also had my own little collection of 45 RPM recordings, which were played on a small machine that could accommodate a whole stack of records and play them back through a small amplifier. Later I acquired a special taste for the piano music of Debussy 
and Ravel through recordings of Walter Gieseking and even learned some of this repertoire eventually.

In those days, believe it or not, the $\mathrm{CBC}$ broadcast a great deal of classical music. Because I was frequently sick at home with asthma as a child, I often listened to a program called Music in the Morning from CBC Windsor, which opened with the main theme of the fourth movement of Brahms's First Racket (as Basil Fawlty would have called it). But there were also recitals of all kinds and a good many special broadcasts of music.

There were few public concerts in those days in the town, outside of Community Concerts, of which there were some four a season. Sometimes the University Women's Club would bring in an artist from elsewhere. Around 1953 the young Glenn Gould played such a concert in the town, and my mother was in charge of looking after him for the day. I was probably considered too young to attend such an event.

But where does composition come into the picture? Why would I want to start writing music, coming from this rather regular world of practising the piano, listening to music, going to school, and riding my bike around everywhere? It seems to have started with "noodling around" on the piano (as Harry Somers referred to it-he seems to have begun his creative life in the same manner). I would start practising the obligatory pieces but would inevitably end up drifting off into my own music, based on melodies and chords that I must have found attractive and satisfying. Some of these I tried to write down, but RCMT theory exams certainly didn't equip anyone for musical creativity in those days. They were strictly about rules on paper. Even more importantly, I think, was the fact that I was hearing music in my head. This was my own imagined music, but it was in the style of the music I heard on the radio or on recordings-often like Mozart or some other classical composer. In a sense, my musical mind was a sponge, soaking up everything and somehow putting out an internal mix of whatever was absorbed. I was also learning about composers of former times by borrowing books about them from the public library. I remember being fascinated in particular by Haydn's life-his father was a wheelwright and he struggled as a young man in Vienna. The biographies were interesting, exotic, with wonderful illustrations. Whether they further stimulated my creativity I have no idea, but at least I knew there was some such a person as a "composer" who wrote all those tricky little piano pieces I was required to practise and then reproduce at yearly Conservatory piano exams.

A landmark in my path to musical creativity was going to the National Music Camp at Interlochen, Michigan, in the summer of 1960, at the age of seventeen. Here I not only had piano lessons but also composition lessons with a composer named Grant Beglarian and wrote some pieces for violin and cello, one of which was performed at the end of the season. (I must have had some notion by that time that I wanted to write down music and to be instructed in it.) The following year I returned to Interlochen, and my teacher that summer was a young George Crumb, before he became the famous George Crumb of a few years later. I wrote a Concerto for Violin and Strings during the seven or eight weeks there, an ambitious project for someone as inexperienced and 
ignorant as I was, but in the meantime I had started studying theory and composition with Sam Dolin at the RCMT. During the winter and spring of 1961, I had written three pieces for string quartet, which were performed at one of Sam's concerts of student compositions in the late spring of 1961. These pieces were the first really serious attempts I made at composition, and I was probably motivated by what was one of the most important musical discoveries of my entire life-the Bartók String Quartets, which had been recorded by the Végh Quartet and released on three Angel LPs in 1954. I was totally enraptured by this music-it was so exotic sounding, there was such great rhythmic vitality, the harmonic language seemed so beautiful, so striking. I did not then know how to analyze this music-I absorbed it as if by osmosis. Of course I tried to emulate all this in my string quartet pieces. In any case, this experience really marked the beginning of my lengthy apprenticeship as a would-be composer, an apprenticeship that really lasted until well into the 1970 .

During the summers at Interlochen I also heard a great deal of music, mostly at concerts, which took place every evening. The programs were varied. I remember hearing the Dvořák New World Symphony here for the first time, not to mention a symphony by Howard Hanson (whose music was very popular) and a young American composer named Walter S. Hartley, who seemed to be able to turn out a new piece every week or so! (Hartley passed away in 2016 at the age of about ninety!) But most importantly, I first heard (on recordings) Stravinsky's Petrushka and Schoenberg's Op. 16 Orchestra Pieces. I was fascinated by these pieces-you never heard any such music where I had come fromand I loved them immediately. I remember vividly first hearing a recording of the opus 16 pieces and discovering this amazing world of dissonant, colourful sounds. I did not have to "acclimatize" myself to its unfamiliar language-it was, quite simply, mesmerizing. So something in me, some part of my musical brain, accepted this music with no qualms. I should also point out that during my entire undergraduate studies for a BMus at the University of Toronto in the early 1960 s there was not a single course or even section of a course that dealt with twentieth-century music. Godfrey Ridout's second-year history course was supposed to go from Beethoven to the present but got sidetracked on Elgar and Ridout and never actually reached anything remotely "modern." The one exception was John Beckwith's fugue class, in which we had to write a fugue in a twentieth-century style.

The question is, again, What was it that made me want to try such an esoteric activity as writing music? And not tonal music, conventional music, I should add. From the time I started "noodling around" I was powerfully drawn to dissonance-whether modal in my early noodles or quite dissonant chromaticism by the time I was writing the string quartet pieces. This did not win encouragement from some corners. I remember Talivaldis Kenins, a well-known Toronto composer, sitting through my quartet pieces in 1961 in the old Conservatory Concert Hall with his hands over his ears. He probably never forgave me for these terrible early efforts. And there were plenty of them. Pieces tried, abandoned, completed, forgotten, sometimes performed, then forgotten, 
pretty much all consigned to oblivion. The question still remains, What made me want to do all this in the first place?

I do not believe that I was trying to express "emotions" in these early pieces. I wanted the music to be expressive, but that's not the same thing. From the beginning I found a certain satisfaction in the act of writing the ideas down, in constructing, putting ideas together, putting sounds together in my own way, on paper-a kind of engineering in sound. Later the structural part became more and more important. Was the writing a search for some sort of beauty? Certainly I searched for ideas, melodic lines that I liked, that I considered attractive, and from the beginning I seemed to have an instinctive sense of the need to invent distinctive material.

But on a larger scale I wonder whether I was, even at that early age, searching for some sort of permanence-something that would transcend my brief existence, even if I didn't really understand such things at that age. I do think that for many the creative act in some way provides a way to deal with the realization of one's mortality. Even if you don't write huge symphonies that probe the meaning of life, like Mahler, this principle is probably at work at some level. You want to create a "legacy." (Now I know better-my legacy is my children and grandchildren, and that's a far more important legacy.) But whether because of some strange genetic coding on one of my chromosomes or faulty wiring in my brain, I did start to try to write music in my late teen-age years. At what point did I become a composer, after all this?

Not for a long time, I believe. At the end of my period of study with Sam Dolin, in the summer of 1963, I wrote a large-scale, three-movement Violin Concerto, motivated only by some strange compulsion that I must write a violin concerto. (Perhaps that long-ago European violinist ancestor was urging me on from the beyond!) There was no commission, no performance in view. In this work, I reached a certain plateau of achievement and I poured everything I had so far learned into the piece. It was an intense experience. But it led nowhere. I naively believed that with this work, if it were good, I would gain some little bit of recognition, a start. No such thing. It was not even performed until many years later, and that was purely a fluke-I believe I was not really meant to hear the work. Then began some years in the compositional "wilderness"- gone were the consolations of hearing my pieces played at Sam's student concerts, gone was the assurance that went with working on the Violin Concerto. Instead, I spent years of uncertainty, many times questioning what I was doing, wondering if I had the ability to do what I was doing.

Probably the most important factor in my compositional growth in these years - the late 1960s - was spending time in Europe and discovering the music of Ligeti, Stockhausen, Kagel, Lachenmann, Zimmerman, and many others. I attended the Darmstadt festival in 1966 and again in 1969 and spent an entire year in Munich in 1969-70 doing research for my $\mathrm{PhD}$ thesis but, on the side, going to concerts and hearing a good deal of recent music. The composers I found most interesting were Ligeti, Kagel, and Zimmerman. All this was enormously stimulating to someone from such a conservative background, and it was this exposure to all kinds of new music that made me want to try things 
beyond the conventional, the expected. During the year in Munich I wrote a piece called Kontakion for ten players in which I tried things that were much bolder than before-e.g., structuring an entire piece around two recurring pitches (sustained and subjected to various timbral changes), with much emphasis on texture and colour, a certain amount of indeterminacy, and virtually nothing in the way of conventional linear writing. In fact, this piece was considered so outrageous by the Toronto musicians who performed it (while I was still in Europe) that they could not refrain from writing nasty comments about me and my music on their parts. I found this quite heartening and encouraging, a real compliment-if the piece had been "standard" fare (i.e. "routine," "boring"), they would never have been so moved. (Only two years later that same piece received a beautiful and sympathetic performance by the Société de musique contemporaine du Québec under the direction of Serge Garant.) When I returned to Toronto in 1970, I brought back with me the awareness of what I had experienced in Europe and continued to explore what were for me new (and I hoped) interesting ways of writing. In the string quartet I wrote in the fall of 1970, for instance, there were certain theatrical things such as playing silently, as if there were a thick pane of glass between the quartet and the listeners, as well as references to other music (and of course certain extended techniques, which many were exploring in those years). However, I believe that it was not until the mid-1970s that I finally wrote pieces with which I was satisfied-which showed a certain level of skill and imagination (but more about the latter ingredient in a minute).

How did this happen? I believe that it happened only after I began teaching at McGill in 1972. For many years thereafter I taught, among other things, the analysis of twentieth-century music and twentieth-century music history. In analyzing, in great detail, the music of Stravinsky, Bartók, the second Viennese school, Varèse, Messiaen, Carter, Boulez, Ligeti, Kagel, and many others, I acquired a detailed knowledge of repertoire and of compositional techniques, including certain parameters I had not thought about much before-a huge range of possibilities enriched all the more by teaching graduate seminars over the years on topics as varied as the Mahler Symphonies and the music of Takemitsu. The insights I gathered in these years, not just the compositional techniques, fed into my creative work and made it far more sophisticated, far richer in detail, in every possible way. Elliott Carter's music in particular influenced my thinking greatly, especially his approach to large-scale organization, making an extended piece a coherent, seamless process of evolution over time.

I should also give credit to the kind of institution McGill was in those years. The theory and composition areas were staffed by people such as Marvin Duchow, Kelsey Jones, Bruce Mather, Bengt Hambraeus, and Alcides Lanza. Istvan Anhalt had only just left McGill to go to Queen's University in Kingston. As a junior staff member, I was acutely aware that a certain level of excellence was expected in teaching theory and composition, and I'm sure that the proximity of such figures as Mather, Hambraeus, and Lanza spurred me on to want to be a better composer. From Bruce Mather's music I came to realize the importance of creating a coherent harmonic language, from both Bengt 
and Alcides, among other things, the importance of colour and imagination in musical creation, and I learned much from their example.

The first work that marked a significant level of achievement, to me, was my String Trio, a CBC commission from David Jaeger, written in the spring and summer of 1976. I remember that I struggled with this piece for some months. It was difficult. But here at last I feel that I achieved something far more accomplished than before, ranging from the open string sounds at the beginning, as if the players are just tuning up, to the strange little piece of tonal music that makes its first appearance during furious and dissonant playing early on in the piece and appears for a last time at the end, disintegrating even as it is heard for the first time nearly in its entirety. What enabled me to do this? Hard to say exactly after all these years, but I think above all that I had developed an awareness of what I was doing, the critical insights that accompanied the creative work, the confidence about putting notes and rhythms together, and a firm idea of the entire arc of the work, thus giving it coherence. But another ingredient was also present-what can we call it? The opening, with its ambiguity as to whether the performers were just tuning up or whether the piece had actually started, taking a chance on sticking into a dissonant piece a short fragment of tonal music that sounded like a quotation but was not, having the three string instruments appear to assume other identities towards the end of the piecehow would all this work out? Did I dare do it? (As T.S. Eliot puts it, "Do I dare / disturb the universe?") Perhaps this ingredient was what we sometimes refer to as imagination-however you define it, it's going beyond the usual, finding special and unexpected ways of doing things, "disturbing the universe." And I believe that it was the presence of a visiting composer at McGill in 1975-76, an Italian-born composer named Mario Bertoncini, who further challenged me to disturb my musical universe.

At that time Mario was known for developing very sophisticated techniques for bowing the strings of the piano. I attended some of his composition seminars and was deeply impressed, above all, by his wonderful imagination: the ability to think of new and unexpected ways of producing sounds, putting them together, reimagining the very nature of a piece of music-its beginning and end, the way instrumental performers interact with each other, the possible theatrical implications of performance-all of these became part of my thinking in the years to come. It was in a solo cello piece called Tangents that I wrote during Mario's time at McGill in which I really "disturbed the universe" far more than before, perhaps. The following brief description will give a sense of how I was "disturbing the universe" in this piece: In Tangents, the cellist is treated at first as a vain, superficial virtuoso who seeks only the adulation of the audience. He or she wants applause, recognition. At first, the piece is very showy and virtuosic, and all goes well. However, eventually, the cellist notices that there is, on stage, a huge array of percussion instruments and a piano (but no other performers). Eventually comes the realization that, unlike the human audience, these instruments are not responding to the cello music, awakening a powerful determination to get a response. The cellist tries to play to the percussion instruments music they will like. No response. The piano, however, 
suddenly begins to emit some vacuous, nineteenth-century piano music. (This was obtained by hiding small speakers in the piano and playing recorded piano music through them.) There ensues a mighty struggle in which the cellist unsuccessfully tries to drown out the piano. Suddenly, the piano stops playing, leaving the cellist alone again with only the resources of the cello itself. The playing then becomes more inward, poetic, thoughtful, leisurely. This is reflected in the notation, in which three large circles containing fragments for improvisation, are joined by lines which touch the circle (thus, "tangents" to the circles).

Imagination is one ingredient in a work of art that is the hardest of all to define, and I doubt whether it can ever be acquired through all the training in the world. Perhaps that's the overriding ingredient I somehow perceived in pieces such as Petrushka and Schoenberg's Op. 16, when I first heard them all those years ago. This thing called imagination remains the elusive but necessary part of any great artistic manifestation. And perhaps that was in part what I spent all those years trying to discover within myself and put into the String Trio. It was a long search.

\begin{abstract}
Brian Cherney reflects on his childhood and youth in Peterborough, Ontario, in the 1940 s and 1950 and his musical studies at the University of Toronto. He considers the varied influence that family, recordings, CBC broadcasts, attending live concerts, piano lessons, reading about music, and spending time in Europe in the late 196os had in shaping his emerging interest in becoming a composer. Cherney considers that it was only in the mid-1970s, after his appointment to McGill in 1972, that he developed the self-awareness, critical insight, and confidence to become a mature composer ... someone who dared, in T.S. Eliot's words, to "disturb the universe."
\end{abstract}

\title{
RÉSUMÉ
}

Brian Cherney réfléchit sur son enfance et sa jeunesse à Peterborough (Ontario) dans les années 1940 et 1950, ainsi que ses études musicales à l'Université de Toronto. Il examine l'influence qu'ont eue, à divers degrés, sa famille, l'écoute d'enregistrements et de radiodiffusions de la $\mathrm{CBC}$, la fréquentation des concerts, les leçons de piano, la lecture d'écrits sur la musique et les séjours en Europe à la fin des années 1960 sur son intérêt croissant pour la composition. Selon lui, ce n'est que vers le milieu des années 1970, après sa nomination à McGill en 1972, qu'il a acquis la conscience de soi, l'esprit critique et la confiance nécessaires pour devenir un compositeur sérieux, quelqu'un qui, pour reprendre les paroles de T.S. Eliot, ose «déranger l'univers».

\section{BIOGRAPHY}

Brian Cherney, the dedicatee of this collection of articles, has been a professor at McGill University for over forty-five years. His colleagues recognized his dedicated work as a teacher of composition, analysis, and Canadian music with an Outstanding Teacher 
Award in 2005. Cherney's catalogue of over 100 compositions for diverse media have been commissioned, performed, and broadcast across Canada and internationally. In addition, he has written a monograph on Harry Somers (1975) and with John Beckwith co-edited a collection of essays about John Weinzweig (2011). He remains intensely active as a professor and a composer and is at work on another book on Somers. 